\title{
Effect of unaffordable medical need on distress level of family member: analyses of 1997-2013 United States National Health Interview Surveys
}

Hui Jun Chih ${ }^{1 *}$ and Wenbin Liang ${ }^{2}$

\begin{abstract}
Background: Reduced funding to public health care systems during economic downturns is a common phenomenon around the world. The effect of health care cost on family members of the patients has not been established. This paper aims to explore the relationship between affordability of health care and vulnerability of family members to distress levels.

Methods: Data of a total of 262,843 participants were obtained from 17 waves (1997-2013) of the United States National Health Interview Survey. Multinomial logistic regression was used to investigate psychological distress level as a result of having family members who experienced unmet medical needs due to cost.

Results: Among participants without family members who experienced unmet needs for medical care due to cost, risks of having 'moderate' (score of 5-12) or 'serious' (score of 13 or above) level of psychological distress were 1.0\% and $11.5 \%$, respectively. Risks of having 'moderate' or 'serious' level of psychological distress were $3.1 \%$ and $23.4 \%$, respectively among participants with family members who experienced unmet needs. The adjusted relative risk ratio of 'moderate' and 'serious', as compared to 'normal' level of psychological distress, were 1.58 (95\% confidence interval: 1. 47-1.69) and 2.09 (95\% confidence interval: 1.78-2.45) if one's family members experienced unmet medical needs.

Conclusions: Unmet medical needs due to cost increases risk of distress levels experienced by family members. Careful planning and adequate funding to public health care system could be implemented to prevent any unnecessary detrimental effect on mental health among family members of the unwell and any further increment of the prevalence of mental illnesses. This recommendation aligns with the World Health Organization Mental Health Action Plan 2013-2020.
\end{abstract}

Keywords: Health care and services, Cost, Mental health, Public health

\section{Background}

Health care systems in many developed countries are funded from public sources to provide equitable access to all based on needs [1]. Despite the idealism in providing equitable access to health care for all, access was not equally distributed across income groups [1]. Increased cost-sharing or more out-of-pocket expenses by patients during economic downturns or reduced health care

\footnotetext{
* Correspondence: h.chih@curtin.edu.au

${ }^{1}$ School of Public Health, Faculty of Health Sciences, Curtin University, GPO

Box U1987, Perth, WA 6845, Australia

Full list of author information is available at the end of the article
}

funding reduced access to health care for some and subsequently increased their susceptibility to some infectious diseases, worsened their conditions of chronic diseases and increased mortality rates [2-4].

While poor access to health care can lead to negative impact on physical health of patients, the cost to access health care may also add to one's family financial burden [5]. The financial burden can negatively impact the family members, who may already be under stress when providing daily care to their ill relatives [6-8]. Their mental health may be suboptimal and yet overlooked. Meanwhile, the World Health Organization (WHO) has highlighted the importance of 
reducing prevalence of mental illness in its Mental Health Action Plan 2013-2020 [9].

A search through the PubMed, Science Direct and Web of Science databases using the following keywords: "unmet medical needs" AND "mental distress" AND "family member" AND "cost" from 1st January 2010 to 1st January 2017 yielded 426 articles. However, after a closer examination, there is no publication on this topic. It is therefore paramount to investigate the impact of unmet medical care and the vulnerability of family members to psychological distress. The aim of this study was to investigate the effect of having a family member with unaffordable medical cost on one's psychological distress level.

\section{Methods}

\section{Study design and setting}

Data from 17 waves (1997-2013) of National Health Interview Survey (NHIS) were collated from Integrated Health Interview Series of United States National Health Interview Survey: Minnesota Population Center and State Health Access Data Assistance Center, Integrated Health Interview Series: Version 5.0. Minneapolis: University of Minnesota, 2012 (http://www.ihis.us). The NHIS was conducted by the National Center for Health Statistics (NCHS), Centers for Disease Control and Prevention to provide estimations of health indictors at national level [10-12].

\section{Participants}

Multistage probability sampling technique was applied to select representative sample of 100,000 people of the wider population $(40,000$ households) every year and weighted for key demographic variables to assure representativeness of the sample (https://www.ihis.us/ihis/ userNotes_sampledesign.shtml).

\section{Measures}

Details of the survey sampling strategy and data collection methods were described elsewhere [10, 12]. Briefly, for this study, one adult aged 18 years or older was selected per family to provide detailed information regarding his/her demographics, access to medical care service, physical and mental health, which included an assessment on nonspecific distress level in the past 30 days using the standard Kessler's 6 (K6) questionnaire [13]. The six questions asked were: "During the past month, how much of the time did you feel ... so sad nothing could cheer you up?"; “... nervous?”; “... restless or fidgety?"; “... hopeless?”; “... that everything was an effort?"; and "... worthless?". Each of the question was scored with zero for "None of the time", one for "A little of the time", two for "Some of the time" and three for "Most of the time" and four for "All of the time", yielding a range from zero to 24. A K6 score of 5-12 was used to indicate presence of 'moderate' mental distress while score of 13-24 was used to indicate presence of 'serious' mental distress
[14]. The questionnaire has good validity and reliability [15] and the cut-off points are clinically validated [14]. In this study, unmet needs of medical care was defined as answering "yes" to the question: "whether during the past 12 months, was there any time when needed medical care, but did not get it because couldn't afford it".

\section{Statistical analyses}

The information obtained from the NCHS was anonymized and de-identified prior to analyses. The effect of having family members who had unmet needs for medical care on the risk of having i) moderate or serious (K6 score $\geq 5$ ) psychological distress level and ii) serious (K6 score 13-24) psychological distress level in the past 30 days were first assessed in two multivariate Poisson regression models. Psychological distress level was further classified into three categories based on their K6 score: 0-4 (normal), 5-12 (moderate) and 13-24 (serious). Multinomial logistic regression was then used to investigate the effect of having family members who had unmet needs for medical care on their psychological distress level. In order to control for the potential confounding effect of participant's health on his/ her distress level, analyses were restricted to participants who: i) were living with two or more members in a single family household; ii) rated their health status as good, very good or excellent; and iii) were free from any limitation due to physical or mental problems, without unmet needs of medical care. Potential confounding factors such as age, gender, race, marital status, highest educational attainment and health status, whether having any family members with activity limitations, family income comparing to poverty threshold and year of survey were controlled for in the multivariate models. Participants with missing information on these potential confounding factors were excluded in the multivariate analysis. Data from a total of 262,843 participants were included. Sampling weight was applied in all analyses [10]. Significance level of 0.05 was applied.

\section{Results}

The risks of having moderate and serious (K6 score $\geq 5$ ) or serious (K6 score $\geq 13$ ) level of psychological distress were $23.4 \%$ and $3.1 \%$, respectively among participants with family members who had unmet needs for medical care. The risks among participants without family members had unmet needs were significantly lower at $11.5 \%$ and $1.0 \%$, respectively. In other words, having family members with unmet needs for medical care were associated with about $100 \%$ and $200 \%$ increase in the risk of having at least moderate and serious level of psychological distress, respectively.

Overall the multivariate analyses showed that the risk of moderate or serious and serious psychological distress level were significantly higher (50\% and $80 \%$, respectively) among participants who had family members with unmet medical needs (Tables 1 and 2). Estimates from both the 
Table 1 Relative risk (RR) of moderate and serious psychological distress level ${ }^{\mathrm{a}}$ in the past month

\begin{tabular}{|c|c|c|c|c|}
\hline \multirow{3}{*}{$\begin{array}{l}\text { Any family member with } \\
\text { unmet need for care }\end{array}$} & \multirow[b]{2}{*}{ No } & \multirow{2}{*}{$\begin{array}{l}\text { RR } \\
1.00\end{array}$} & \multicolumn{2}{|c|}{$\begin{array}{l}\text { 95\% confidence } \\
\text { interval of RR }\end{array}$} \\
\hline & & & & \\
\hline & Yes & 1.45 & 1.38 & 1.52 \\
\hline \multirow{2}{*}{$\begin{array}{l}\text { Any family member } \\
\text { with activity limitation }\end{array}$} & No & 1.00 & & \\
\hline & Yes & 1.32 & 1.27 & 1.36 \\
\hline \multirow[t]{7}{*}{ Age } & $18-24$ & 1.00 & & \\
\hline & $25-34$ & 0.92 & 0.88 & 0.96 \\
\hline & $35-44$ & 0.85 & 0.81 & 0.89 \\
\hline & $45-54$ & 0.76 & 0.72 & 0.80 \\
\hline & $55-64$ & 0.58 & 0.54 & 0.61 \\
\hline & $65-74$ & 0.43 & 0.40 & 0.47 \\
\hline & $75+$ & 0.38 & 0.34 & 0.43 \\
\hline \multirow[t]{2}{*}{ Gender } & Male & 1.00 & & \\
\hline & Female & 1.29 & 1.26 & 1.33 \\
\hline \multirow[t]{3}{*}{ Race } & White & 1.00 & & \\
\hline & Black & 0.85 & 0.82 & 0.89 \\
\hline & Other & 0.90 & 0.86 & 0.95 \\
\hline \multirow[t]{7}{*}{ Marital status } & $\begin{array}{l}\text { Married, spouse } \\
\text { present }\end{array}$ & 1.00 & & \\
\hline & $\begin{array}{l}\text { Married, spouse } \\
\text { absent }\end{array}$ & 1.31 & 1.13 & 1.51 \\
\hline & Separated & 1.59 & 1.48 & 1.70 \\
\hline & Divorced & 1.35 & 1.28 & 1.42 \\
\hline & Widowed & 1.65 & 1.50 & 1.81 \\
\hline & Living with partner & 1.28 & 1.22 & 1.34 \\
\hline & Never married & 1.23 & 1.17 & 1.28 \\
\hline \multirow[t]{9}{*}{ Education level } & $\begin{array}{l}\text { Never attended/ } \\
\text { kindergarten only }\end{array}$ & 0.99 & 0.80 & 1.23 \\
\hline & Grade $1,2,3$, or 4 & 0.91 & 0.79 & 1.04 \\
\hline & Grade 5,6 , or 7 & 0.86 & 0.79 & 0.94 \\
\hline & Grade 8 & 1.03 & 0.92 & 1.15 \\
\hline & Grade 9,10 , or 11 & 1.10 & 1.05 & 1.16 \\
\hline & Grade 12 & 0.99 & 0.96 & 1.03 \\
\hline & 1 to 3 years of college & 1.00 & & \\
\hline & $\begin{array}{l}4 \text { years college/ } \\
\text { Bachelor's degree }\end{array}$ & 0.83 & 0.80 & 0.87 \\
\hline & $5+$ years of college & 0.81 & 0.76 & 0.85 \\
\hline \multirow[t]{3}{*}{ Health Status } & Excellent & 1.00 & & \\
\hline & Very Good & 1.38 & 1.33 & 1.42 \\
\hline & Good & 1.88 & 1.82 & 1.95 \\
\hline \multirow{4}{*}{$\begin{array}{l}\text { Ratio of family income } \\
\text { to poverty threshold }\end{array}$} & $<1.00$ & 1.22 & 1.16 & 1.28 \\
\hline & $1.00-1.99$ & 1.16 & 1.11 & 1.21 \\
\hline & $2.00-3.99$ & 1.09 & 1.06 & 1.13 \\
\hline & $4.00+$ & 1.00 & & \\
\hline
\end{tabular}

Table 1 Relative risk (RR) of moderate and serious psychological distress level ${ }^{a}$ in the past month (Continued)

\begin{tabular}{lllll}
\hline Year of survey & 1997 & 1.00 & & \\
1998 & 0.96 & 0.90 & 1.02 \\
1999 & 0.82 & 0.77 & 0.88 \\
2000 & 0.84 & 0.79 & 0.90 \\
2001 & 1.08 & 1.02 & 1.15 \\
2002 & 0.85 & 0.80 & 0.91 \\
2003 & 0.90 & 0.84 & 0.96 \\
2004 & 0.93 & 0.87 & 0.99 \\
2005 & 0.91 & 0.85 & 0.97 \\
2006 & 0.82 & 0.76 & 0.89 \\
2007 & 0.74 & 0.68 & 0.80 \\
2008 & 0.89 & 0.83 & 0.96 \\
2009 & 0.93 & 0.87 & 1.00 \\
2010 & 0.93 & 0.87 & 0.99 \\
2011 & 0.77 & 0.72 & 0.83 \\
2012 & 0.72 & 0.67 & 0.77 \\
2013 & 1.01 & 0.95 & 1.08 \\
\hline a & & &
\end{tabular}

${ }^{a}$ K6 score $\geq 5$

multivariate Poisson regression models and multinomial logistic regressions (Table 3) are consistent with the findings from univariate analysis albeit the effects become smaller after controlling for confounding variables.

\section{Discussion}

In the past, reduction or removal of health care funding in some countries contributed to poorer patients' health outcomes as they could not afford medical care due to cost. This study provides a new insight by directly measuring the relationship between unmet medical care, specifically due to cost, and the vulnerability of family members (not just the main care-giver) to psychological distress. In this study, it was found that health care cost, when linked to unmet medical needs, affected psychological distress level of family members. Specifically, family members of those with unmet medical needs due to cost are at a significantly higher risk of suffering from 'moderate' and 'serious' level of psychological distress, as assessed by the $\mathrm{K} 6$ scale. The risk is comparable to those with a history of epilepsy [16].

A person may experience high psychological distress when they have to make decision when there are conflicts in the choice, and has to 'trade-off between attributes' [17]. Family members of patients with unmet medical needs may have to go through 'distressed financing' [18] to provide for the unaffordable treatment while sacrificing other needs. Perceived likelihood of negative consequences increases conflicts during their decision making, which can lead to perceived difficult 
Table 2 Relative risk (RR) of serious psychological distress level ${ }^{\mathrm{a}}$ in the past month

\begin{tabular}{|c|c|c|c|c|}
\hline \multirow{3}{*}{$\begin{array}{l}\text { Any family member with } \\
\text { unmet need for care }\end{array}$} & \multirow[b]{2}{*}{ No } & \multirow{2}{*}{$\begin{array}{l}\text { RR } \\
1.00\end{array}$} & \multicolumn{2}{|c|}{$\begin{array}{l}\text { 95\% confidence } \\
\text { interval of RR }\end{array}$} \\
\hline & & & & \\
\hline & Yes & 1.84 & 1.58 & 2.15 \\
\hline \multirow{2}{*}{$\begin{array}{l}\text { Any family member } \\
\text { with activity limitation }\end{array}$} & No & 1.00 & & \\
\hline & Yes & 1.5 & 1.38 & 1.73 \\
\hline \multirow[t]{7}{*}{ Age } & $18-24$ & 1.00 & & \\
\hline & $25-34$ & 0.96 & 0.82 & 1.12 \\
\hline & $35-44$ & 0.90 & 0.76 & 1.06 \\
\hline & $45-54$ & 0.82 & 0.68 & 0.98 \\
\hline & $55-64$ & 0.56 & 0.45 & 0.70 \\
\hline & $65-74$ & 0.45 & 0.34 & 0.60 \\
\hline & $75+$ & 0.32 & 0.22 & 0.46 \\
\hline \multirow[t]{2}{*}{ Gender } & Male & 1.00 & & \\
\hline & Female & 1.58 & 1.43 & 1.75 \\
\hline \multirow[t]{3}{*}{ Race } & White & 1.00 & & \\
\hline & Black & 0.86 & 0.75 & 0.99 \\
\hline & Other & 1.01 & 0.84 & 1.20 \\
\hline \multirow[t]{7}{*}{ Marital status } & $\begin{array}{l}\text { Married, spouse } \\
\text { present }\end{array}$ & 1.00 & & \\
\hline & $\begin{array}{l}\text { Married, spouse } \\
\text { absent }\end{array}$ & 1.61 & 1.10 & 2.36 \\
\hline & Separated & 2.16 & 1.76 & 2.65 \\
\hline & Divorced & 1.63 & 1.38 & 1.92 \\
\hline & Widowed & 2.26 & 1.69 & 3.02 \\
\hline & Living with partner & 1.34 & 1.14 & 1.57 \\
\hline & Never married & 1.26 & 1.08 & 1.47 \\
\hline \multirow[t]{9}{*}{ Education level } & $\begin{array}{l}\text { Never attended/ } \\
\text { kindergarten only }\end{array}$ & 1.66 & 0.84 & 3.28 \\
\hline & Grade $1,2,3$, or 4 & 1.60 & 1.14 & 2.24 \\
\hline & Grade 5,6 , or 7 & 1.20 & 0.94 & 1.54 \\
\hline & Grade 8 & 1.72 & 1.24 & 2.39 \\
\hline & Grade 9,10 , or 11 & 1.53 & 1.31 & 1.79 \\
\hline & Grade 12 & 1.12 & 1.00 & 1.26 \\
\hline & 1 to 3 years of college & 1.00 & & \\
\hline & $\begin{array}{l}4 \text { years college/ } \\
\text { Bachelor's degree }\end{array}$ & 0.62 & 0.52 & 0.74 \\
\hline & $5+$ years of college & 0.53 & 0.41 & 0.67 \\
\hline \multirow[t]{3}{*}{ Health Status } & Excellent & 1.00 & & \\
\hline & Very Good & 1.26 & 1.12 & 1.43 \\
\hline & Good & 2.09 & 1.85 & 2.36 \\
\hline \multirow{4}{*}{$\begin{array}{l}\text { Ratio of family income } \\
\text { to poverty threshold }\end{array}$} & $<1.00$ & 1.87 & 1.58 & 2.21 \\
\hline & $1.00-1.99$ & 1.52 & 1.31 & 1.77 \\
\hline & $2.00-3.99$ & 1.23 & 1.07 & 1.40 \\
\hline & $4.00+$ & 1.00 & & \\
\hline
\end{tabular}

Table 2 Relative risk (RR) of serious psychological distress level ${ }^{a}$ in the past month (Continued)

\begin{tabular}{lllll}
\hline Year of survey & 1997 & 1.00 & & \\
1998 & 0.82 & 0.66 & 1.01 \\
1999 & 0.68 & 0.54 & 0.86 \\
2000 & 0.94 & 0.76 & 1.17 \\
2001 & 0.88 & 0.72 & 1.09 \\
2002 & 0.98 & 0.78 & 1.22 \\
2003 & 0.92 & 0.74 & 1.14 \\
2004 & 0.76 & 0.59 & 0.97 \\
2005 & 0.69 & 0.55 & 0.87 \\
2006 & 0.76 & 0.59 & 0.98 \\
2007 & 0.67 & 0.51 & 0.89 \\
2008 & 0.68 & 0.53 & 0.88 \\
2009 & 0.75 & 0.58 & 0.97 \\
2010 & 0.80 & 0.64 & 1.01 \\
2011 & 0.66 & 0.52 & 0.84 \\
2012 & 0.64 & 0.49 & 0.82 \\
2013 & 1.01 & 0.81 & 1.26 \\
\hline
\end{tabular}

${ }^{\mathrm{a}} \mathrm{K} 6$ score $\geq 13$

circumstance and increased distress level [17]. It should also be noted that unsecured debt is strongly associated with mental health issues including depression, substance use and suicide [19].

Adequate resources can maintain if not prevent ill health outcome [20]. Effective preventative approaches such as implementing mental health first aid program at rural or urban communities, including but not limited to workplaces or learning environment for general public, teachers and future health professionals [21-24] can be applied in various settings as an early preventative strategy. Systematic documentation of medical and administration costs incurred at various stages of the treatment at various departments and by health professionals as well as barriers to effective care plan can allow better management of 'cost for value' for the patients [25, 26]. Quality tools and resources to support organizational improvement integral to high-quality primary care such as coordinated home care program $[27,28]$ may also be adopted in and out of hospital. Effectiveness of these services in preventing mental illnesses can also be tested in communities in order to provide evidence-based recommendation to decision makers and funding bodies. As part of the planning, it is important to assure that the services are easily accessible as they can mitigate the risk of mental illness of the vulnerable group [29].

The detrimental impact on the mental health of these family members is not exclusive to those living in the United States of America (USA) but everyone who has to undergo difficult decision making process, particularly 
Table 3 Relative risk ratio (RRR) of moderate ${ }^{a}$ and of serious ${ }^{b}$ psychological distress levels in the past month

\begin{tabular}{|c|c|c|c|c|c|c|c|}
\hline & & \multicolumn{3}{|c|}{$\begin{array}{l}\text { 'Moderate' psychological } \\
\text { distress level }\end{array}$} & \multicolumn{3}{|c|}{$\begin{array}{l}\text { Very high' psychological } \\
\text { distress level }\end{array}$} \\
\hline & & \multirow{2}{*}{$\begin{array}{l}\text { Adjusted } \\
\text { RRR }^{c} \\
1.00\end{array}$} & \multicolumn{2}{|c|}{$\begin{array}{l}95 \% \text { confidence } \\
\text { interval of adjusted } \\
\text { RRR }\end{array}$} & \multirow{2}{*}{$\begin{array}{l}\begin{array}{l}\text { Adjusted } \\
\text { RRR }^{C}\end{array} \\
1.00\end{array}$} & \multicolumn{2}{|c|}{$\begin{array}{l}\text { 95\% confidence } \\
\text { interval of adjusted } \\
\text { RRR }\end{array}$} \\
\hline \multirow[t]{2}{*}{ Any family member with unmet need for care } & No & & & & & & \\
\hline & Yes & 1.58 & 1.47 & 1.69 & 2.09 & 1.78 & 2.45 \\
\hline \multirow[t]{2}{*}{ Any family member with activity limitation } & No & 1.00 & & & 1.00 & & \\
\hline & Yes & 1.38 & 1.32 & 1.44 & 1.66 & 1.47 & 1.87 \\
\hline \multirow[t]{7}{*}{ Age } & $18-24$ & 1.00 & & & 1.00 & & \\
\hline & $25-34$ & 0.90 & 0.85 & 0.95 & 0.94 & 0.80 & 1.10 \\
\hline & $35-44$ & 0.82 & 0.77 & 0.87 & 0.86 & 0.73 & 1.02 \\
\hline & $45-54$ & 0.71 & 0.67 & 0.77 & 0.76 & 0.63 & 0.92 \\
\hline & $55-64$ & 0.53 & 0.49 & 0.57 & 0.50 & 0.40 & 0.63 \\
\hline & $65-74$ & 0.38 & 0.34 & 0.42 & 0.39 & 0.29 & 0.52 \\
\hline & $75+$ & 0.33 & 0.29 & 0.38 & 0.27 & 0.18 & 0.39 \\
\hline \multirow[t]{2}{*}{ Gender } & Male & 1.00 & & & 1.00 & & \\
\hline & Female & 1.33 & 1.28 & 1.37 & 1.67 & 1.51 & 1.85 \\
\hline \multirow[t]{3}{*}{ Race } & White & 1.00 & & & 1.00 & & \\
\hline & Black & 0.82 & 0.78 & 0.87 & 0.83 & 0.72 & 0.96 \\
\hline & Other & 0.87 & 0.82 & 0.93 & 0.98 & 0.82 & 1.18 \\
\hline \multirow[t]{7}{*}{ Marital status } & Married, spouse present & 1.00 & & & 1.00 & & \\
\hline & Married, spouse absent & 1.34 & 1.56 & 1.89 & 1.71 & 2.01 & 3.08 \\
\hline & Separated & 1.72 & 1.31 & 1.49 & 2.49 & 1.46 & 2.07 \\
\hline & Divorced & 1.40 & 1.52 & 1.94 & 1.74 & 1.84 & 3.38 \\
\hline & Widowed & 1.72 & 1.26 & 1.41 & 2.49 & 1.20 & 1.66 \\
\hline & Living with partner & 1.34 & 1.20 & 1.35 & 1.41 & 1.12 & 1.54 \\
\hline & Never married & 1.27 & 1.11 & 1.63 & 1.31 & 1.15 & 2.54 \\
\hline \multirow[t]{9}{*}{ Education level } & Never attended/ kindergarten only & 0.91 & 0.70 & 1.20 & 1.65 & 0.81 & 3.35 \\
\hline & Grade $1,2,3$, or 4 & 0.81 & 0.67 & 0.97 & 1.55 & 1.09 & 2.21 \\
\hline & Grade 5,6 , or 7 & 0.80 & 0.71 & 0.89 & 1.16 & 0.90 & 1.49 \\
\hline & Grade 8 & 0.96 & 0.83 & 1.11 & 1.73 & 1.23 & 2.43 \\
\hline & Grade 9,10 , or 11 & 1.09 & 1.02 & 1.17 & 1.58 & 1.34 & 1.86 \\
\hline & Grade 12 & 0.98 & 0.94 & 1.02 & 1.12 & 0.99 & 1.26 \\
\hline & 1 to 3 years of college & 1.00 & & & 1.00 & & \\
\hline & 4 years college/ Bachelor's degree & 0.83 & 0.78 & 0.87 & 0.60 & 0.50 & 0.73 \\
\hline & $5+$ years of college & 0.81 & 0.76 & 0.87 & 0.52 & 0.40 & 0.66 \\
\hline \multirow[t]{3}{*}{ Health Status } & Excellent & 1.00 & & & 1.00 & & \\
\hline & Very Good & 1.46 & 1.40 & 1.52 & 1.33 & 1.17 & 1.51 \\
\hline & Good & 2.10 & 2.01 & 2.19 & 2.39 & 2.11 & 2.70 \\
\hline \multirow[t]{4}{*}{ Ratio of family income to poverty threshold } & $<1.00$ & 1.22 & 1.14 & 1.30 & 1.96 & 1.65 & 2.33 \\
\hline & $1.00-1.99$ & 1.16 & 1.10 & 1.22 & 1.56 & 1.34 & 1.81 \\
\hline & $2.00-3.99$ & 1.09 & 1.05 & 1.14 & 1.23 & 1.08 & 1.41 \\
\hline & $4.00+$ & 1.00 & & & 1.00 & & \\
\hline
\end{tabular}


Table 3 Relative risk ratio (RRR) of moderate ${ }^{a}$ and of serious ${ }^{b}$ psychological distress levels in the past month (Continued)

\begin{tabular}{|c|c|c|c|c|c|c|c|}
\hline \multirow[t]{17}{*}{ Year of survey } & 1997 & 1.00 & & & 1.00 & 0.65 & 1.01 \\
\hline & 1998 & 0.97 & 0.89 & 1.05 & 0.81 & 0.51 & 0.83 \\
\hline & 1999 & 0.80 & 0.74 & 0.88 & 0.65 & 0.72 & 1.14 \\
\hline & 2000 & 0.80 & 0.74 & 0.87 & 0.91 & 0.72 & 1.12 \\
\hline & 2001 & 1.12 & 1.04 & 1.21 & 0.90 & 0.75 & 1.19 \\
\hline & 2002 & 0.81 & 0.75 & 0.89 & 0.94 & 0.71 & 1.12 \\
\hline & 2003 & 0.88 & 0.81 & 0.96 & 0.89 & 0.58 & 0.96 \\
\hline & 2004 & 0.93 & 0.86 & 1.01 & 0.74 & 0.53 & 0.85 \\
\hline & 2005 & 0.91 & 0.84 & 0.99 & 0.67 & 0.56 & 0.95 \\
\hline & 2006 & 0.80 & 0.72 & 0.88 & 0.73 & 0.48 & 0.84 \\
\hline & 2007 & 0.70 & 0.64 & 0.78 & 0.63 & 0.51 & 0.86 \\
\hline & 2008 & 0.89 & 0.81 & 0.98 & 0.66 & 0.57 & 0.96 \\
\hline & 2009 & 0.93 & 0.86 & 1.02 & 0.74 & 0.62 & 0.99 \\
\hline & 2010 & 0.93 & 0.85 & 1.01 & 0.78 & 0.49 & 0.80 \\
\hline & 2011 & 0.75 & 0.69 & 0.81 & 0.62 & 0.46 & 0.77 \\
\hline & 2012 & 0.69 & 0.63 & 0.75 & 0.59 & 0.81 & 1.27 \\
\hline & 2013 & 1.02 & 0.94 & 1.10 & 1.02 & 0.65 & 1.01 \\
\hline
\end{tabular}

a 6 score of $5-12$

${ }^{b} \mathrm{~K} 6$ score $\geq 13$

c Adjusted for age, gender, race, marital status, highest educational attainment and health status of the main participants, whether having any family members with activity limitations, family income comparing to poverty threshold and year of survey

when the demand of illness is not static [5] and there are dynamic economic changes. The insured ones are not exempted as there are still co-payments and other out-ofpockets expenses $[4,30]$, which can continue to add to the burden. Due to the high prevalence and disease burden of mental disorders, it is important for clinicians and world leaders to note these preventable consequences and minimize the risk, as in alignment with the WHO Mental Health Action Plan 2013-2020 [9].

This study used a large representative sample of the USA population. The conclusion is thus representative of the wider USA population because it provided a more accurate estimate of the risk of having psychological distress due to unmet medical needs of family members. Due to the nature of cross-sectional design, long term impact on the family members' distress level is not assessable in this study, particularly when the $K 6$ scale only measures the psychological distress level over a 30 day period. Nevertheless, it is possible that the family members would continue to suffer from psychological distress as their loved ones have unmet medical needs [30]. This further warrants the need to assure adequate provision of resources and preventative health care for the public.

\section{Conclusions}

It is highlighted from this study that unmet medical needs can affect psychological distress of family members, not just the patients themselves. Specifically, family members of those with unmet medical needs due to cost are at a significantly higher risk of 'moderate' and 'serious' level of psychological distress. These important findings need to be taken into consideration while shaping the funding for our health care systems in order to avoid detrimental effect on mental health of the otherwise healthy family members and to prevent further rise in the prevalence of mental illnesses. This recommendation aligns with the WHO Mental Health Action Plan 2013-2020.

\section{Abbreviations}

K6: Kessler's 6; NCHS: National Center for Health Statistics; NHIS: National Health Interview Survey; RR: Relative risk; RR: Relative risk ratio; USA: United States of America; WHO: World Health Organization

\section{Acknowledgements}

Not applicable.

\section{Funding}

This research received no specific grant from any funding agency, commercial or not-for-profit sectors. WL is employed at the National Drug Research Institute at Curtin University, which is supported by funding from the Australian Government under the Substance Misuse Prevention and Service Improvement Grants Fund.

Availability of data and materials

The datasets analysed during the current study are available from the NHIS repository, http://www.ihis.us.

\section{Authors' contributions}

WL conceptualized the idea. HJC and WL analysed and interpreted the data. Both authors contributed to, read and approved of the final manuscript. 


\section{Ethics approval and consent to participate}

The study was approved by Research Ethics Review Board of the United States NCHS, an institutional ethics committee (Protocol \# 2009-16) [10].

\section{Consent for publication}

Not applicable.

\section{Competing interests}

The authors declare that they have no competing interests.

\section{Publisher's Note}

Springer Nature remains neutral with regard to jurisdictional claims in published maps and institutional affiliations.

\section{Author details}

'School of Public Health, Faculty of Health Sciences, Curtin University, GPO Box U1987, Perth, WA 6845, Australia. ${ }^{2}$ National Drug Research Institute, Faculty of Health Sciences, Curtin University, GPO Box U1987, Perth, WA 6845, Australia.

Received: 8 March 2017 Accepted: 23 August 2017

Published online: 02 September 2017

\section{References}

1. van Doorslaer E, Masseria C, Koolman X, for the OECD Health Equity Research Group. Inequalities in access to medical care by income in developed countries. Can Med Assoc J. 2006;174(2):177-83.

2. Brinda EM, Kowal P, Attermann J, Enemark U. Health service use, out-ofpocket payments and catastrophic health expenditure among older people in India: The WHO Study on global AGEing and adult health (SAGE). J Epidemiol Community Health. 2015;69(5):489-94.

3. Karanikolos M, Mladovsky P, Cylus J, Thomson S, Basu S, Stuckler D, Mackenbach JP, McKee M. Financial crisis, austerity, and health in Europe. Lancet. 2013;381(9874):1323-31.

4. Suhrcke M, Stuckler D, Suk JE, Desai M, Senek M, McKee M, Tsolova S, Basu S, Abubakar I, Hunter P, et al. The impact of economic crises on communicable disease transmission and control: a systematic review of the evidence. PLoS ONE. 2011;6(6):e20724.

5. Sales E. Family burden and quality of life. Qual Life Res. 2003;12(1):33-41.

6. Bevans M, Sternberg EM. Caregiving burden, stress, and health effects among family caregivers of adult cancer patients. JAMA. 2012;307(4):398-403.

7. Dillon-Wallace J, McDonagh S, Fordham L. How stable is the well-being of Australian mothers who care for young children with special health care needs? J Child Fam Stud. 2014;23(7):1215-26.

8. Drummond A, Looman WS, Phillips A. Coping among parents of children with special health care needs with and without a health care home. J Pediatr Health Care. 2012;26(4):266-75.

9. World Health Organization. Mental health action plan 2013-2020. Geneva: World Health Organization; 2013.

10. National Center for Health Statistics. Survey Description, National Health Interview Survey, 2013. Maryland: Centers for Disease Control and Prevention, U.S. Department of Health and Human Services; 2014

11. Parsons V, Moriarity C, Jonas K, Moore T, Davis K, Tompkins L. Design and estimation for the national health interview survey, 2006-2015. In: Vital and health statistics Series 2, Data evaluation and methods research. 2014.

12. National Center for Health Statistics. National Health Interview Survey: research for the 1995-2004 redesign, vol. 126. National Ctr for Health Statistics; 1999

13. Kessler RC, Green JG, Gruber MJ, Sampson NA, Bromet E, Cuitan M, Furukawa TA, Gureje O, Hinkov H, Hu C-Y, et al. Screening for serious mental illness in the general population with the K6 screening scale: results from the WHO World Mental Health (WMH) survey initiative. Int J Methods Psychiatr Res. 2010;19(S1):4-22.

14. Prochaska JJ, Sung H-Y, Max W, Shi Y, Ong M. Validity study of the K6 scale as a measure of moderate mental distress based on mental health treatment need and utilization. Int J Methods Psychiatr Res. 2012;21(2):88-97.

15. Kessler RC, Barker PR, Colpe LJ, Epstein JF, Gfroerer JC, Hiripi E, Howes MJ, Normand S-LT, Manderscheid RW, Walters EE. Screening for serious mental illness in the general population. Arch Gen Psychiatry. 2003;60(2):184-9.
16. Moore LJ, Elliott JO, Lu B, Klatte ET, Charyton C. Serious psychological distress among persons with epilepsy based on the 2005 California Health Interview Survey. Epilepsia. 2009;50(5):1077-84.

17. Luce MF, Bettman JR, Payne JW. Choice processing in emotionally difficult decisions. J Exp Psychol Learn Mem Cogn. 1997;23(2):384-405.

18. Joe W. Distressed financing of household out-of-pocket health care payments in India: incidence and correlates. Health Policy Plan. 2015;30(6):728-41.

19. Richardson T, Elliott P, Roberts R. The relationship between personal unsecured debt and mental and physical health: a systematic review and meta-analysis. Clin Psychol Rev. 2013;33(8):1148-62.

20. Williamson AB, D'Este CA, Clapham KF, Eades SJ, Redman S, Raphael B. Psychological distress in carers of Aboriginal children in urban New South Wales: findings from SEARCH (phase one). Med J Aust. 2016;205(1):27-32.

21. Kitchener BA, Jorm AF. Mental health first aid training for the public: evaluation of effects on knowledge, attitudes and helping behavior. BMC Psychiatry. 2002;2(1):10.

22. Kitchener BA, Jorm AF. Mental health first aid training in a workplace setting: a randomized controlled trial [ISRCTN13249129]. BMC Psychiatry. 2004;4(1):23.

23. Jorm AF, Kitchener BA, Sawyer MG, Scales H, Cvetkovski S. Mental health first aid training for high school teachers: a cluster randomized trial. BMC Psychiatry. 2010;10(1):51.

24. Crawford G, Burns SK, Chih HJ, Hunt K, Tilley PM, Hallett J, Coleman K, Smith S. Mental health first aid training for nursing students: a protocol for a pragmatic randomised controlled trial in a large university. BMC Psychiatry. 2015;15(1):26.

25. Marck CH, Weil J, Lane H, Weiland TJ, Philip J, Boughey M, Jelinek GA. Care of the dying cancer patient in the emergency department: findings from a National survey of Australian emergency department clinicians. Intern Med J. 2014;44(4):362-8.

26. Porter ME. What is value in health care? N Engl J Med. 2010;363(26):2477-81.

27. Cresp R, Clarke K, McAuley KE, McAullay D, Moylan CA, Peter S, Chaney GM, Cook A, Edmond KM. Effectiveness of the Koorliny Moort out-of-hospital health care program for Aboriginal and Torres Strait Islander children in Western Australia. Med J Aust. 2016;204(5):197. e191-197.

28. Janamian T, Upham SJ, Crossland L, Jackson CL. Quality tools and resources to support organisational improvement integral to high-quality primary care: a systematic review of published and grey literature. Med J Aust. 2016; 204(7):S22-8.

29. Barnes MC, Donovan JL, Wilson C, Chatwin J, Davies R, Potokar J, Kapur N, Hawton K, O'Connor R, Gunnell D. Seeking help in times of economic hardship: access, experiences of services and unmet need. BMC Psychiatry. 2017;17(1):84.

30. Francoeur RB. Reformulating financial problems and interventions to improve psychosocial and functional outcomes in cancer patients and their families. J Psychosoc Oncol. 2001;19(1):1-20

\section{Submit your next manuscript to BioMed Central} and we will help you at every step:

- We accept pre-submission inquiries

- Our selector tool helps you to find the most relevant journal

- We provide round the clock customer support

- Convenient online submission

- Thorough peer review

- Inclusion in PubMed and all major indexing services

- Maximum visibility for your research

Submit your manuscript at www.biomedcentral.com/submit
Biomed Central 